\title{
Papers
}

\section{Being big or growing fast: systematic review of size and growth in infancy and later obesity}

Janis Baird, David Fisher, Patricia Lucas, Jos Kleijnen, Helen Roberts, Catherine Law

\begin{abstract}
Objectives To assess the association between infant size or growth and subsequent obesity and to determine if any association has been stable over time.

Design Systematic review.

Data sources Medline, Embase, bibliographies of included studies, contact with first authors of included studies and other experts.

Inclusion criteria Studies that assessed the relation between infant size or growth during the first two years of life and subsequent obesity.

Main outcome measure Obesity at any age after infancy. Results 24 studies met the inclusion criteria (22 cohort and two case-control studies). Of these, 18 assessed the relation between infant size and subsequent obesity, most showing that infants who were defined as "obese" or who were at the highest end of the distribution for weight or body mass index were at increased risk of obesity. Compared with non-obese infants, in those who had been obese odds ratios or relative risks for subsequent obesity ranged from 1.35 to 9.38 . Ten studies assessed the relation of infant growth with subsequent obesity and most showed that infants who grew more rapidly were at increased risk of obesity. Compared with other infants, in infants with rapid growth odds ratios and relative risks of later obesity ranged from 1.17 to 5.70 . Associations were consistent for obesity at different ages and for people born over a period from 1927 to 1994.

Conclusions Infants who are at the highest end of the distribution for weight or body mass index or who grow rapidly during infancy are at increased risk of subsequent obesity.
\end{abstract}

\section{Introduction}

Levels of overweight and obesity have increased markedly during the past decade in all age groups. ${ }^{12}$ The UK government has set a target to halt the year on year rise in obesity in children aged $\leq 11$ by 2010 as part of an overall strategy to tackle the rising prevalence of obesity in the population. Given the lack of evidence of effective treatments, action to achieve this target must focus mainly on prevention. ${ }^{3}$ It is not clear, however, how early in life prevention could begin.

Observational evidence suggests that faster growth during childhood is associated with an increased risk of obesity in later life, ${ }^{45}$ suggesting that interventions aimed at modifying childhood growth could prevent adult obesity. Recent studies in the US and Finland have shown that patterns of growth during infancy may be associated with both childhood and adult obesity, ${ }^{67}$ suggesting the potential for intervention during infancy. The precise patterns of growth leading to obesity are unclear and both infant size and infant growth have been implicated. ${ }^{7}$

We carried out a systematic review to assess the association between infant growth and subsequent obesity and to establish whether groups of infants with particular patterns of growth are at greater risk. We considered both size and growth because each is important in understanding the growth status of an infant-for example, an infant may be small but be growing rapidly. Given secular trends in children's growth, ${ }^{8}$ we also assessed whether any associations identified in the past are likely to apply to infants now.

\section{Methods}

This research was part of a wider review of scientific evidence on infant growth and health and wellbeing throughout the life course, which was carried out alongside a review of lay perspectives on infant size and growth, supplemented by individual and focus group interviews (J Baird et al, Defining optimal infant growth for lifetime health: a systematic review of lay and scientific literature (unpublished report)).

We sought studies that described the relation between any aspect of infant growth or size and the development of overweight or obesity at any later age. Studies of infant size were eligible for inclusion if they reported at least one measurement of infant size between 3 months and 2 years. We included studies of infant growth if they reported at least two measurements of size up to 2 years, of which at least one was between 3 months and 2 years.

The outcomes we considered were overweight or obesity. We did not specify a definition of obesity as studies may have been published before currently accepted definitions were introduced. ${ }^{9}$ We did not impose any limits in relation to language, study timing, or setting.

We searched Medline and Embase from their start dates to June 2005 and hand searched the bibliographies of all included studies. We also contacted first authors of included studies and other experts to identify further published or unpublished analyses.

We followed the methods recommended by the Centre for Reviews and Dissemination. ${ }^{10}$ Study quality was assessed by using a checklist and summarised as to whether there was a low, medium, or high risk of bias for study results. The confounding factors we considered important in the relation between infant size or growth and obesity were socioeconomic status, parental size, and method of infant feeding. 
Our approach to synthesis was mainly narrative but we explored the potential for meta-analysis according to standard procedures. $^{10}$

\section{Results}

We identified 27949 references. Screening of abstracts and reference lists identified 24 studies that met our inclusion criteria. All 24 studies were observational (22 cohort studies and two case-control). All but two studies were based in developed countries.

We considered that 15 studies were at medium risk of bias, six at high risk, and three at low risk. Common sources of bias were insufficient description of participants, high rates of attrition, and inadequate consideration of confounding factors.

\section{Studies of infant size}

Eighteen studies assessed the relation between infant size and obesity at ages ranging from 3 to 35 years (table 1). Most focused on "infant obesity" defined in various ways or on infants at the highest end of the distribution of weight or body mass index. Year of birth of infants was 1927 to 1992. Sixteen were cohort studies, two were case-control studies, and all but one were set in developed countries.

Eleven studies described infant obesity with varying definitions based on body mass index, ${ }^{11-15}$ weight, weight for height ${ }^{16-20}$ or skinfold thickness ${ }^{21}$ (table 1). When reporting the findings of these studies we have used the term infant obesity to describe exposure status, though we recognise that the definition of infant obesity is controversial. The seven other studies assessed infant size in terms of weight, ${ }^{62-24}$ weight for height, ${ }^{2526}$ or body mass index ${ }^{7}$ without using a definition of infant obesity.

All studies used centile points in body mass index, skinfolds, weight for height, or a clinical definition to define obesity as an outcome. Six studies focused on obesity in childhood up to the age of 10: four of these defined obesity according to weight for height t $^{18} 2023$ and two according to body mass index. ${ }^{622}$ Five studies focused on obesity in adolescence (9-18 years), three defining obesity by body mass index ${ }^{14}{ }^{15}$ and two using weight. ${ }^{24}{ }^{25}$ Seven studies described adult obesity, four using body mass index to define obesity ${ }^{711-13}$ and three using weight or skinfold thickness measurements. ${ }^{161}{ }^{21}$ Most of the studies in adults were of those aged 20-35 years. ${ }^{711-13} 162126$

\begin{tabular}{|c|c|c|c|c|c|c|}
\hline Study & $\begin{array}{l}\text { No of subjects, } \\
\text { year of birth }\end{array}$ & $\begin{array}{l}\text { Measure of infant } \\
\text { size }\end{array}$ & Definition of obesity & Analysis & Size of effect & $\begin{array}{c}\text { Risk of } \\
\text { bias }\end{array}$ \\
\hline $\begin{array}{l}\text { Mossberg }(1989)^{26} \\
\text { Stockholm, Sweden }\end{array}$ & $\begin{array}{l}27 \text { (sex not } \\
\text { reported), 1927-47 }\end{array}$ & $\begin{array}{l}\text { Diagnosed as } \\
\text { clinically obese by } \\
\text { age } 2 \text { years }\end{array}$ & $\begin{array}{l}\text { Weight for height SD } \\
\text { scores at } 40-50 \text { years } v \\
\text { reference population }\end{array}$ & $\begin{array}{l}\text { Weight for height SD scores with } \\
\text { obesity reported in infancy and at } \\
\text { follow-up in adulthood }\end{array}$ & $\begin{array}{l}\text { SD scores (SE of mean): } 2.3(0.31) \text { on admission; } \\
1.8 \text { ( } 0.46) \text { in late childhood; } 0.2(0.28) \text { in adulthood } \\
\text { (40-50 years) }\end{array}$ & High \\
\hline Guo $(1994)^{3}$ USA & $\begin{array}{l}555(50 \% \text { male }) \\
1929-60\end{array}$ & $\begin{array}{l}\text { BMI at } 75 \text { th centile } \\
v 50 \text { th centile }\end{array}$ & $\begin{array}{l}\mathrm{BMI}>28 \mathrm{~kg} / \mathrm{m}^{2}(\mathrm{men}) \text { or } \\
>26 \mathrm{~kg} / \mathrm{m}^{2} \text { (women) at } \\
35 \text { years }\end{array}$ & $\begin{array}{l}\text { Logistic regression giving odds } \\
\text { ratio for overweight in adulthood } \\
\text { by higher BMI centile in infancy } v \\
\text { lower one (50th, } 75 \text { th centiles } \\
\text { used) }\end{array}$ & $\begin{array}{l}\text { Odds ratios }(95 \% \mathrm{Cl}) \text { at } 1 \text { year } 1.48(0.99 \text { to } 2.21) \\
\text { for males, } 1.54(1.01 \text { to } 2.35) \text { for females; at } 2 \\
\text { years } 1.63(1.04 \text { to } 2.54) \text { for males, } 1.51 \text { ( } 0.96 \text { to } \\
2.38) \text { for females }\end{array}$ & Medium \\
\hline $\begin{array}{l}\text { Eriksson }(2003)^{7} \\
\text { Helsinki, Finland }\end{array}$ & $\begin{array}{l}2135 \text { male, } 2380 \\
\text { female, } 1933-44\end{array}$ & BMI at 6 months & $\begin{array}{l}\text { Maximum lifetime risk } \\
\text { of obesity defined as } \\
\text { BMI } \geq 30 \mathrm{~kg} / \mathrm{m}^{2} \text { at } 60-70 \\
\text { years }\end{array}$ & $\begin{array}{l}\text { Incidence (\%) of adult obesity in } \\
\text { each of four BMI categories at } 6 \\
\text { months }\end{array}$ & $\begin{array}{l}\text { Cumulative incidence }(95 \% \mathrm{Cl}) \text { : males: } 28.6(24.1 \\
\text { to } 33.1) \text { in lowest } 6 \text { month group }\left(<16.3 \mathrm{~kg} / \mathrm{m}^{2}\right) \text {, } \\
44.1(40.0 \text { to } 48.5) \text { in highest } 6 \text { month group } \\
\left(>18.0 \mathrm{~kg} / \mathrm{m}^{2}\right), P<0.0001 \text { for trend; females: } 27.5 \\
(23.8 \text { to } 31.3) \text { in lowest } 6 \text { month group }(<16.3 \\
\left.\mathrm{kg} / \mathrm{m}^{2}\right), 36.8(32.0 \text { to } 41.7) \text { in highest } 6 \text { month } \\
\text { group }\left(>18.0 \mathrm{~kg} / \mathrm{m}^{2}\right), P=0.001 \text { for trend }\end{array}$ & Medium \\
\hline $\begin{array}{l}\text { Heald }(1965)^{24} \\
\text { Washington DC; } \\
\text { Massachusetts, } \\
\text { USA }\end{array}$ & $\begin{array}{l}158 \text { cases, } 94 \\
\text { controls (all } \\
\text { female), } 1945-50\end{array}$ & 1 year weight $(\mathrm{lb})$ & $\begin{array}{l}\text { Cases (clinically obese) } \\
\text { and controls (not obese) } \\
\text { at mean age } 15 \text { years }\end{array}$ & $\begin{array}{l}\text { Mean values for infant size } \\
\text { reported for cases and controls, } \\
\text { with SDs and } t \text { tests for } \\
\text { differences }\end{array}$ & $\begin{array}{l}\text { Mean difference in } 1 \text { year weight }(\mathrm{lb}) \text { : } \\
\text { cases-controls } 1.446(\mathrm{P}=0.009)\end{array}$ & High \\
\hline $\begin{array}{l}\text { Charney }(1976)^{16} \\
\text { Rochester, USA }\end{array}$ & $\begin{array}{l}366 \text { (sex not } \\
\text { reported), 1945-55 }\end{array}$ & $\begin{array}{l}\text { Infant obesity: } \\
\text { weight centile } \\
>90 \% \text { at } 3 \text { and } 6 \\
\text { months }\end{array}$ & $\begin{array}{l}\text { Weight } \geq 20 \% \text { above } \\
\text { median for height and } \\
\text { age at } 20-30 \text { years }\end{array}$ & $\begin{array}{l}\text { Contingency tables of heavy, } \\
\text { average, and light infants and } \\
\text { underweight, normal, overweight, } \\
\text { and obese adults, from which } \\
\text { relative risks of adult obesity in } \\
\text { "obese" } v \text { non-obese infants were } \\
\text { derived }\end{array}$ & $\begin{array}{l}\text { Relative risks: } 1.63 \text { ( } 1.14 \text { to } 2.33) \text { for unadjusted } \\
(n=366), 1.81(0.96 \text { to } 3.44) \text { for neither parent } \\
\text { overweight ( } n=225), 3.37(1.69 \text { to } 6.70) \text { for at least } \\
\text { one parent overweight }(n=110) \text {, and } 2.51 \text { ( } 2.25 \text { to } \\
2.80 \text { ) for combined ( } n=335)\end{array}$ & High \\
\hline $\begin{array}{l}\text { Asher }(1966)^{17} \\
\text { Birmingham, UK }\end{array}$ & $\begin{array}{l}137 \text { (sex not } \\
\text { reported): } 21 \\
\text { cases, } 24 \text { controls, } \\
1950\end{array}$ & $\begin{array}{l}\text { Infant obesity: } \\
\text { weight }>90 \text { th } \\
\text { centile at } 6 \\
\text { months; }>97 \text { th } \\
\text { centile at } 6 \\
\text { months }\end{array}$ & $\begin{array}{l}\text { Childhood obesity: } \\
\text { weight }>90 \text { th centile at } \\
3-5 \text { years; weight for } \\
\text { height }>97 \text { th centile at } 5 \\
\text { years }\end{array}$ & $\begin{array}{l}\text { Relative risk for child obesity in } \\
\text { "obese" } v \text { non-obese infants }\end{array}$ & $\begin{array}{l}\text { Relative risks: } 9.33(0.52 \text { to } 167) \text { for weight }>90 \text { th } \\
\text { centile at } 3-5 \text { years; } 6.56(2.90 \text { to } 14.8) \text { for weight } \\
\text { for height }>97 \text { th centile at } 5 \text { years }\end{array}$ & High \\
\hline $\begin{array}{l}\text { Rolland-Cachera } \\
(1987)^{12} \text { France }\end{array}$ & $\begin{array}{l}164(52 \% \text { male }) \text {, } \\
1950\end{array}$ & $\begin{array}{l}\text { Infant obesity: BMI } \\
>75 \text { th centile at } 1 \\
\text { year }\end{array}$ & $\begin{array}{l}\mathrm{BMI}>75 \mathrm{th} \text { centile: }>23.4 \\
\mathrm{~kg} / \mathrm{m}^{2} \text { (men) or } \\
>22.3 \mathrm{~kg} / \mathrm{m}^{2} \text { (women) at } \\
21 \text { years }\end{array}$ & $\begin{array}{l}\text { Relative risk of obesity at } 21 \\
\text { years in "obese" } v \text { non-obese } \\
\text { infants }\end{array}$ & Relative risk $(95 \% \mathrm{Cl}) 2.76$ (1.32 to 5.77$)$ & Medium \\
\hline $\begin{array}{l}\text { Garn }(1985)^{21} \\
\text { Tecumseh, USA }\end{array}$ & $\begin{array}{l}135(39 \% \text { male }) \\
1957-60\end{array}$ & $\begin{array}{l}\text { Infant obesity at } 1 \\
\text { or } 2 \text { years: triceps } \\
\text { skinfold }>85 \text { th } \\
\text { centile for age/sex. } \\
\text { Same definition for } \\
\text { subscapular } \\
\text { skinfold }\end{array}$ & $\begin{array}{l}\text { Same definitions as for } \\
\text { infancy at 21-22 years }\end{array}$ & $\begin{array}{l}\text { Percentage of "obese" infants } \\
\text { who remained obese } 20 \text { years } \\
\text { later, with P value for deviation } \\
\text { from chance figure of } 15 \% \text { (with } \\
\text { binomial test) }\end{array}$ & $\begin{array}{l}\text { Percentage of obese infant (triceps): } 33.3 \% \\
(P=0.21) \text { at } 1-21 \text { years; } 18.2 \%(P=0.77) \text { at } 2-22 \\
\text { years; percentage of obese infant (subscapular) } \\
33.3 \%(P=0.21) \text { at } 1-21 \text { years; } 20.0 \%(P=0.66) \text { at } \\
2-22 \text { years }\end{array}$ & Medium \\
\hline $\begin{array}{l}\text { Johnston }(1978)^{25} \\
\text { Philadelphia, USA }\end{array}$ & $\begin{array}{l}798(51 \% \text { male }) \\
1958-65\end{array}$ & $\begin{array}{l}\text { Relative weight: } \\
\text { weight for height } \\
\geq 1 \text { SD at 1year } \\
\text { (high) } v \leq-1 \text { at } 1 \\
\text { year (low) }\end{array}$ & $\begin{array}{l}\text { At } 9-15 \text { years: relative } \\
\text { weight (predicted } \\
\text { weight/actual weight) } \\
\geq 120 \% \text {; triceps skinfold } \\
>90 \text { th centile for age, } \\
\text { sex/race }\end{array}$ & $\begin{array}{l}\text { Relative risk of obesity at ages } \\
9-15 \text { years, according to whether } \\
\text { subjects had high or low relative } \\
\text { weight or skinfold thickness at } 1 \\
\text { year, stratified for sex }\end{array}$ & $\begin{array}{l}\text { Relative risk }(95 \% \mathrm{Cl}) \text { for relative weight } 3.75(2.15 \\
\text { to } 6.54) \text { for males, } 4.06(2.52 \text { to } 6.53) \text { for females; } \\
\text { for triceps skinfold } 2.97(2.03 \text { to } 4.35) \text { for males, } \\
2.70(1.74 \text { to } 4.17) \text { for females }\end{array}$ & High \\
\hline
\end{tabular}




\begin{tabular}{|c|c|c|c|c|c|c|}
\hline Study & $\begin{array}{l}\text { No of subjects, } \\
\text { year of birth }\end{array}$ & $\begin{array}{l}\text { Measure of infant } \\
\text { size }\end{array}$ & Definition of obesity & Analysis & Size of effect & $\begin{array}{l}\text { Risk of } \\
\text { bias }\end{array}$ \\
\hline $\begin{array}{l}\text { Wilkinson }(1977)^{23} \\
\text { Newcastle upon } \\
\text { Tyne, UK }\end{array}$ & $\begin{array}{l}48 \text { cases; } 48 \\
\text { controls }(42 \% \\
\text { male), } 1960-2\end{array}$ & $\begin{array}{l}\text { Weight at } 6 \text { and } \\
12 \text { months (obese } \\
>90 \text { th centile) }\end{array}$ & $\begin{array}{l}\text { Obesity at } 10 \text { years, } \\
\text { defined as weight for } \\
\text { height }>97 \text { th centile. } \\
\text { Controls defined as } \\
\text { weight for height } \\
\text { 25th-75th centile }\end{array}$ & $\begin{array}{l}\text { Odds ratio of obesity at } 10 \text { years } \\
\text { according to weight at } 6 \text { and } 12 \\
\text { months }\end{array}$ & $\begin{array}{l}\text { Odds ratio }(95 \% \mathrm{Cl}) \text { of obesity at } 10 \text { years in } \\
\text { children who had been obese at } 6 \text { or } 12 \text { months } v \\
\text { non-obese infants: } 6 \text { month weight }(n=48) 2.00 \\
(0.88 \text { to } 4.56) ; 12 \text { month weight }(n=42) 1.62(0.63 \\
\text { to } 4.15)\end{array}$ & Medium \\
\hline $\begin{array}{l}\text { Whitaker (1997) } \\
\text { Washington State, } \\
\text { USA }\end{array}$ & $\begin{array}{l}854(36 \% \text { male }) \\
1965-70\end{array}$ & $\begin{array}{l}\text { Infant obesity: BMI } \\
>85 \text { th centile } \\
\text { (obese) or }>95 \text { th } \\
\text { (very obese) at } 1-2 \\
\text { years }\end{array}$ & $\begin{array}{l}\text { BMI } \geq 27.8 \mathrm{~kg} / \mathrm{m}^{2} \text { (men) } \\
\text { or } \geq 27.3 \mathrm{~kg} / \mathrm{m}^{2} \text { (women) } \\
\text { at } 25 \text { years }\end{array}$ & $\begin{array}{l}\text { Logistic regression giving odds } \\
\text { ratios for obesity in adulthood by } \\
\text { whether "obese"' or "very obese"' } \\
\text { in infancy } v \text { "not obese" }\end{array}$ & $\begin{array}{l}\text { Odds ratio (unadjusted): } 1.3 \text { ( } 0.7 \text { to } 2.5 \text { ) for obese } \\
\text { or very obese; } 2.0 \text { ( } 0.7 \text { to } 5.7 \text { ) for very obese } \\
\text { (findings remained non-significant after adjustment } \\
\text { for parental obesity) }\end{array}$ & Medium \\
\hline $\begin{array}{l}\text { Poskitt }(1977)^{18} \\
\text { Dudley, UK }\end{array}$ & $\begin{array}{l}203(49 \% \text { male }) \\
1968-70\end{array}$ & $\begin{array}{l}\text { Percentage weight } \\
\text { at age when height } \\
\text { is at } 50 \text { th centile, } \\
\text { measured at } \\
\text { around } 5 \text { months } \\
\text { (obese }>120 \% \text { ) }\end{array}$ & Same, at around 5 years & $\begin{array}{l}\text { Relative risk of childhood obesity } \\
\text { at } 5 \text { years of age for "obese" } \\
\text { infants } v \text { non-obese infants }\end{array}$ & Relative risk (95\% Cl) 9.38 (1.64 to 53.6) & Medium \\
\hline $\begin{array}{l}\text { Tienboon }(2002)^{15} \\
\text { New South Wales, } \\
\text { Australia }\end{array}$ & $\begin{array}{l}83(48 \% \text { male }), \\
1972\end{array}$ & $\begin{array}{l}\text { BMI }>1 \text { SD from } \\
\text { group mean for } \\
\text { age at } 1 \text { year }\end{array}$ & $\begin{array}{l}\mathrm{BMI}>1 \mathrm{SD} \text { from group } \\
\text { mean at } 15 \text { years }\end{array}$ & $\begin{array}{l}\text { Relative risk of obesity at } 15 \\
\text { years for "obese" } v \text { non-obese } \\
\text { infants }\end{array}$ & Relative risk $(95 \% \mathrm{Cl}) 2.03$ (0.47 to 8.82$)$ & Medium \\
\hline $\begin{array}{l}\text { He (1999) } \\
\text { Gothenburg, } \\
\text { Sweden }\end{array}$ & $\begin{array}{l}3650 \text { (51\% male), } \\
1972-5\end{array}$ & $\begin{array}{l}\text { Infant obesity: BMI } \\
>18 \mathrm{~kg} / \mathrm{m}^{2} \text { (both } \\
\text { sexes) at } 1-2 \text { years }\end{array}$ & $\begin{array}{l}\mathrm{BMI} \geq 25 \mathrm{~kg} / \mathrm{m}^{2} \\
\text { (both sexes) at } 18 \text { years }\end{array}$ & $\begin{array}{l}\text { Odds ratio of obesity at } 18 \text { years } \\
\text { according to whether "obese" at } \\
1 \text { or } 2 \text { years }\end{array}$ & $\begin{array}{l}\text { Odds ratio } 995 \% \mathrm{Cl}) \text { at } 1 \text { year: } 1.62 \text { ( } 1.10 \text { to } 2.38) \\
\text { for males, } 2.31(1.57 \text { to } 3.41) \text { for females, } 1.93 \\
\text { (1.47 to } 2.54) \text { for both; at } 2 \text { years: } 3.00 \text { ( } 2.03 \text { to } \\
4.43 \text { ) for males, } 2.90 \text { ( } 1.95 \text { to } 4.31 \text { ) for females, } \\
2.92 \text { (2.22 to } 3.86 \text { ) for both }\end{array}$ & Medium \\
\hline $\begin{array}{l}\text { Monteiro }(2003)^{19} \\
\text { Pelotas, Brazil }\end{array}$ & $\begin{array}{l}1041 \text { (52\% male), } \\
1982\end{array}$ & $\begin{array}{l}\text { Weight for height } \\
\text { SD score at } 2 \\
\text { years }\end{array}$ & $\begin{array}{l}\mathrm{BMI} \geq 85 \text { th centile at } 14-16 \\
\text { years }\end{array}$ & $\begin{array}{l}6 \text { Odds ratio of overweight and } \\
\text { obesity in adolescence associated } \\
\text { with } 1 \text { unit change in infancy z } \\
\text { scores for size }\end{array}$ & $\begin{array}{l}\text { Unadjusted odds ratio (cut off }+1 \text { SD at } 2 \text { years) } \\
3.54 \text { ( } 2.53 \text { to } 4.96) \text {; odds ratio for } 1 \text { unit } z \text { score } \\
\text { increase in weight for height SD } 1.35 \text { ( } 1.53 \text { to } \\
\text { 1.73) adjusted for socioeconomic status, } \\
\text { maternal size, and infant feeding }\end{array}$ & Low \\
\hline Stettler $(2002)^{6}$ USA & $\begin{array}{l}19397(50 \% \\
\text { male), } 1985-90\end{array}$ & $\begin{array}{l}\text { Infant size: weight } \\
\text { at } 1 \text { year }(\mathrm{g})\end{array}$ & $\begin{array}{l}\text { BMI >95th centile for age } \\
\text { and sex at } 7 \text { years }\end{array}$ & $\begin{array}{l}\text { Logistic regression giving odds } \\
\text { ratio for risk of overweight at } 7 \\
\text { years according to each unit } \\
(100 \mathrm{~g}) \text { increase in weight at } 1 \\
\text { year }\end{array}$ & $\begin{array}{l}\text { Odds ratios }(95 \% \mathrm{Cl}): 1.05(1.04 \text { to } 1.05) \\
\text { unadjusted, } 1.50(1.38 \text { to } 1.63) \text { adjusted for sex, } \\
\text { birth weight, maternal BMI, and education }\end{array}$ & Medium \\
\hline$\overline{\text { Mei }(2003)^{20} \text { USA }}$ & $\begin{array}{l}380518(51 \% \\
\text { male), } 1986-90\end{array}$ & $\begin{array}{l}\text { Weight for height } \\
\geq 95 \text { th centile at } \\
0-11 \text { months (1); } \\
\text { weight for height } \\
\geq 95 \text { th centile at } \\
12-23 \text { months (2) }\end{array}$ & $\begin{array}{l}\text { Weight for height } \geq 95 \text { th } \\
\text { centile at } 24-35 \text { months } \\
\text { (3); weight for height } \\
\geq 95 \text { th centile at } 36-47 \\
\text { months (4) }\end{array}$ & $\begin{array}{l}\text { Relative risk of childhood obesity } \\
\text { according to infant obesity } \\
\text { category. No confidence intervals } \\
\text { reported }\end{array}$ & $\begin{array}{l}\text { Relative risk } 3.3 \text { for (1) and (3), } 2.9 \text { for (1) and } \\
\text { (4), 6.4 for (2) and (3), } 5.3 \text { for (2) and (4) }\end{array}$ & Medium \\
\hline $\begin{array}{l}\text { Reilly }(2005)^{22} \text { Avon, } \\
\text { UK }\end{array}$ & $\begin{array}{l}857 \text { (sex not } \\
\text { stated for infant } \\
\text { growth analysis } \\
51 \% \text { in entire } \\
\text { cohort), } 1991-2\end{array}$ & $\begin{array}{l}\text { Weight SD scores } \\
\text { at } 8 \text { and } 18 \\
\text { months }\end{array}$ & $\begin{array}{l}\text { Obesity at age } 7 \text { years, } \\
\text { defined as BMI } \geq 95 \text { th } \\
\text { centile relative to UK } 1990 \\
\text { reference population }\end{array}$ & $\begin{array}{l}\text { Logistic regression giving odds } \\
\text { ratio of obesity at } 7 \text { years of age } \\
\text { for children in highest quarter for } \\
\text { weight SD score at } 18 \text { months } v \\
\text { children in other quarters }\end{array}$ & $\begin{array}{l}\text { Odds ratio }(95 \% \mathrm{Cl}) \text { for weight at } 8 \text { months: } \\
3.03(1.89 \text { to } 4.85) \text { unadjusted, } 3.13 \text { ( } 1.43 \text { to } \\
6.85) \text { adjusted; weight at } 18 \text { months: } 3.71 \text { ( } 2.29 \\
\text { to } 6.00) \text { unadjusted, } 2.65 \text { (1.25 to } 5.59) \text { adjusted } \\
\text { (adjusted for birth weight, maternal smoking, } \\
\text { parental obesity, hours of sleep at age } 30 \\
\text { months, time spent watching television at } 30 \\
\text { months, diet, maternal education, sex) }\end{array}$ & Low \\
\hline
\end{tabular}

There was considerable consistency in study findings. Eleven studies found that infants who were heavier during infancy or were defined as obese were more likely to develop obesity in childhood, ${ }^{6} 182022$ adolescence, ${ }^{14} 192425$ and adulthood. ${ }^{72} 16$

Six studies related infant size to obesity in childhood. Four found that infants who had been obese ${ }^{18}{ }^{20}$ or who were in the highest end of the distribution for weight ${ }^{62}$ were more likely to be obese at age 5-7 years than non-obese infants, with odds ratios ranging from 1.50 to 9.38 . Three of the studies were based on cohorts of children born since $1985 .^{6}{ }^{20} 22$ The fourth was of children born between 1968 and 1970, suggesting that these relations have been consistent over time. ${ }^{18}$ Of the two other studies in childhood, one study failed to show an association. ${ }^{23}$ The other study failed to show an association in the overall sample, though did find an increased risk of obesity at 5 years in a subsample of infants who had been obese. ${ }^{17}$

Of the five studies of adolescence, four found that larger size in infancy was related to increased risk of obesity at 9-18 years. ${ }^{14} 192425$ Effect sizes ranged between relative risk of 1.35 and odds ratio of 3.0 for adolescent obesity in infants at the highest end of the weight distribution ${ }^{1924}$ or in obese compared with non-obese infants. ${ }^{14}$ The years of birth ranged from 1945 to
1982, suggesting that these relations have been consistent over time. In the remaining study the direction of the association, though not significant, was consistent with the findings of the other studies. ${ }^{15}$

Of the seven studies in adulthood, three reported significant associations between infant size and later obesity. Two studies showed that obese infants were more likely to be obese as young adults at ages 20-30 years than non-obese infants, ${ }^{12}{ }^{16}$ and the third found that larger size at 6 months of age was associated with increased lifetime risk of obesity. ${ }^{7}$ The findings of three other studies of adults suggested a positive relation between infant size and later obesity but were not significant. ${ }^{11}{ }^{13} 21$ The final study, which was based on only 27 participants, failed to show an association. ${ }^{26}$ Year of birth in the studies of adults ranged between 1929 and 1970, suggesting that associations have been consistent over time.

\section{Studies of infant growth}

Ten studies assessed the relation between infant growth and subsequent obesity (table 2). Nine were cohort studies, ${ }^{6} 19$ 22 27-32 and one was a case-control study. ${ }^{24}$ Definitions of infant growth varied. Eight studies used weight gain during the first year of 


\begin{tabular}{|c|c|c|c|c|c|c|}
\hline Study & $\begin{array}{l}\text { No of subjects, } \\
\text { year of birth }\end{array}$ & $\begin{array}{l}\text { Measure of infant } \\
\text { growth }\end{array}$ & Definition of obesity & Analysis & Size of effect & Risk of bias \\
\hline $\begin{array}{l}\text { Heald }(1965)^{24} \\
\text { Washington DC/ } \\
\text { Massachusetts, } \\
\text { USA }\end{array}$ & $\begin{array}{l}158 \text { cases } 94 \\
\text { controls (all } \\
\text { female), } \\
1945-50\end{array}$ & $\begin{array}{l}\text { Weight (Ib) or } \\
\text { height (in) gain } \\
\text { from } 0-6,6-12 \text {, } \\
\text { and } 0-12 \text { months }\end{array}$ & $\begin{array}{l}\text { Cases and controls } \\
\text { defined for outcome } \\
\text { (obesity) at mean age } \\
15 \text { years }\end{array}$ & $\begin{array}{l}\text { Difference in mean values for } \\
\text { weight or height gain at } \\
\text { various intervals in infancy for } \\
\text { cases and controls }\end{array}$ & $\begin{array}{l}\text { For cases-controls: }+0.540(P=0.174) \text { for weight } \\
\text { gain (Ib) } 0-6 \text { months, }+0.565(P=0.206) \text { for height } \\
\text { gain (in) } 0-6 \text { months, }+1.586(P=0.003) \text { for weight } \\
\text { gain (Ib) } 0-1 \text { year, }+0.558(P=0.262) \text { for height gain } \\
\text { (in) } 0 \text { to } 1 \text { year, }+0.842(P=0.144) \text { for weight gain } \\
\text { (lb) 6-12 months, }+0.035(P=0.904) \text { for height gain } \\
\text { (in) 6-12 months }\end{array}$ & High \\
\hline Stettler $(2002)^{6}$ USA & $\begin{array}{l}19397(50 \% \\
\text { male), } 1959-65\end{array}$ & $\begin{array}{l}\text { Growth from birth } \\
\text { to } 4 \text { months } \\
\text { (g/month) }\end{array}$ & $\begin{array}{l}\text { BMI >95th centile for } \\
\text { age and sex at } 7 \text { years }\end{array}$ & $\begin{array}{l}\text { Logistic regression giving odds } \\
\text { ratio for obesity at } 7 \text { years by } \\
\text { rate of weight gain from birth } \\
\text { to } 4 \text { months in units of } 100 \\
\text { g/month }\end{array}$ & $\begin{array}{l}\text { Odds ratio (95\% Cl): } 1.29 \text { (1.25 to } 1.33 \text { ) } \\
\text { unadjusted, } 1.17 \text { (1.11 to } 1.24 \text { ) adjusted (adjusted } \\
\text { for sex, birth weight, maternal BMI, and education } \\
\text { and other size/growth variable) }\end{array}$ & Medium \\
\hline $\begin{array}{l}\text { Stettler }(2003)^{27} \\
\text { Philadelphia, USA }\end{array}$ & $\begin{array}{l}300(54 \% \\
\text { male), } 1959-66\end{array}$ & $\begin{array}{l}\text { Increase in weight } \\
\text { for age score } \geq 1 \\
\text { SD above mean } \\
\text { from birth to } 4 \\
\text { months (rapid } \\
\text { weight gain) }\end{array}$ & $\begin{array}{l}\mathrm{BMI} \geq 30 \mathrm{~kg} / \mathrm{m}^{2} \text { at } 20 \\
\text { years }\end{array}$ & $\begin{array}{l}\text { Logistic regression giving odds } \\
\text { ratios for risk of obesity or } \\
\text { overweight at } 20 \text { years by } \\
\text { presence of rapid weight gain } \\
\text { from birth to } 4 \text { months }\end{array}$ & $\begin{array}{l}\text { Odds ratios }(95 \% \mathrm{Cl}): 2.73(1.20 \text { to } 6.23) \\
\text { unadjusted, } 5.22(1.55 \text { to } 17.6) \text { adjusted for } \\
\text { maternal size and education, birth weight and sex }\end{array}$ & Medium \\
\hline $\begin{array}{l}\text { Eid }(1970)^{28} \\
\text { Sheffield, UK }\end{array}$ & $\begin{array}{l}224(54 \% \\
\text { male), } 1961\end{array}$ & $\begin{array}{l}\text { Weight gain }>90 \text { th } \\
\text { centile over first } 6 \\
\text { months of life } \\
\text { (rapid weight gain) }\end{array}$ & $\begin{array}{l}\text { Weight }>20 \% \text { over } \\
\text { expected for height and } \\
\text { sex at around } 8 \text { years }\end{array}$ & $\begin{array}{l}\text { Relative risk of obesity at } 8 \\
\text { years associated with rapid } \\
\text { weight gain up to } 6 \text { months of } \\
\text { age }\end{array}$ & Relative risk $(95 \% \mathrm{Cl}) 4.05$ (0.94 to 17.5$)$ & Medium \\
\hline $\begin{array}{l}\text { Mellbin }(1973)^{29} \\
\text { Uppsala, Sweden } \\
\text { (Medline) }\end{array}$ & $\begin{array}{l}465 \text { males } 507 \\
\text { female, } 1965\end{array}$ & $\begin{array}{l}\text { Rapid growth: } \\
\text { weight gain over } \\
1 \text { st year } \geq 7.5 \mathrm{~kg} \text {, } \\
\text { or weight gain } \\
\text { over months } 1-4 \\
\text { and } 9-12>97 \text { th } \\
\text { centile for age }\end{array}$ & $\begin{array}{l}\text { Weight }>20 \% \text { above } \\
\text { standard for height at } 7 \\
\text { years }\end{array}$ & $\begin{array}{l}\text { Relative risk of childhood } \\
\text { obesity by infant weight gain } \\
\text { ("rapid" or "normal") }\end{array}$ & $\begin{array}{l}\text { Relative risk }(95 \% \mathrm{Cl}) \text { for weight gain over } 1 \text { st year } \\
\geq 7.5 \mathrm{~kg}: 2.32(0.76 \text { to } 7.07) \text { for males, } 1.72(0.60 \text { to } \\
4.94) \text { for females ; for weight gain over months } 1-4 \\
\text { and } 9-12>97 \text { th centile for age: } 16.9 \text { ( } 4.70 \text { to } 61.0) \\
\text { for males, } 1.33(0.46 \text { to } 3.86) \text { for females }\end{array}$ & Medium \\
\hline $\begin{array}{l}\text { Stettler }(2005)^{31} \\
\text { lowa, USA }\end{array}$ & $\begin{array}{l}653(52.4 \% \\
\text { male), } 1965-78\end{array}$ & $\begin{array}{l}\text { Weight gain from } \\
\text { birth to } 112 \text { days } \\
\text { of age }(\mathrm{g})\end{array}$ & $\begin{array}{l}\text { Weight gain from birth } \\
\text { to } 112 \text { days of age }(\mathrm{g})\end{array}$ & $\begin{array}{l}\text { Logistic regression giving odds } \\
\text { ratio }(95 \% \mathrm{Cl}) \text { for adult } \\
\text { overweight according to both } \\
\text { absolute weight gain }(\mathrm{g}) \text { and } \\
\text { changes in weight for age } \mathrm{SD} \\
\text { score between birth and } 132 \\
\text { days }\end{array}$ & $\begin{array}{l}\text { Odds ratio }(95 \% \mathrm{Cl} \text { ) for weight gain (expressed in } \\
100 \mathrm{~g} \text { units). } 1.04 \text { (1.01 to } 1.08) \text {, for change in } \\
\text { weight for age } \mathrm{SD} \text { score. } 1.41 \text { (1.09 to } 1.82) \\
\text { (adjusted for birth weight, sex, type of formula feed, } \\
\text { parental overweight status, subject's income) }\end{array}$ & Medium \\
\hline $\begin{array}{c}\text { Monteiro }(2003)^{19} \\
\text { Pelotas, Brazil }\end{array}$ & $\begin{array}{l}1041(52 \% \\
\text { male), } 1982\end{array}$ & $\begin{array}{l}\text { Weight-for-height } \\
\text { SD score at 2years } \\
\text { ("rapid growth": } \\
>0.67 \text { z score } \\
\text { change 0-2 years) }\end{array}$ & $\begin{array}{l}\text { BMI } \geq 85 \text { th centile at } \\
14-16 \text { years }\end{array}$ & $\begin{array}{l}\text { Odds ratio of overweight and } \\
\text { obesity in adolescence } \\
\text { associated with rapid growth }\end{array}$ & $\begin{array}{l}\text { Odds ratio }(95 \% \mathrm{Cl}) \text { of overweight and obesity at } \\
14-16 \text { years } 1.66(1.20 \text { to } 2.31) \text { adjusted for } \\
\text { socioeconomic status, maternal size, and infant } \\
\text { feeding }\end{array}$ & Low \\
\hline $\begin{array}{l}\text { Stettler }(2002)^{30} \\
\text { Seychelles }\end{array}$ & $\begin{array}{l}5514(49 \% \\
\text { male), } 1985-90\end{array}$ & $\begin{array}{l}\text { Weight gain during } \\
1 \text { st year of life } \\
(\mathrm{kg})\end{array}$ & $\begin{array}{l}\text { Obesity, using } \\
\text { international obesity } \\
\text { task force charts at } \\
\text { ages } 4.5-17.4 \text { years }\end{array}$ & $\begin{array}{l}\text { Logistic regression giving odds } \\
\text { ratio }(95 \% \mathrm{Cl}) \text { for childhood } \\
\text { overweight and obesity } \\
\text { according to rate of weight } \\
\text { gain in first year (rapid } v \\
\text { normal) }\end{array}$ & $\begin{array}{l}\text { Odds ratio }(95 \% \mathrm{Cl}) 1.62(1.39 \text { to } 1.88) \text { unadjusted, } \\
1.59(1.29 \text { to } 1.97) \text { adjusted for age, sex, maternal } \\
\mathrm{BMI} \text {, and parental occupation }\end{array}$ & Low \\
\hline $\begin{array}{l}\text { Reilly }(2005)^{22} \text { Avon, } \\
\text { UK }\end{array}$ & $\begin{array}{l}857 \text { (\% male } \\
\text { not stated for } \\
\text { infant growth } \\
\text { analysis, } 51 \% \text { in } \\
\text { entire cohort), } \\
1991-2\end{array}$ & $\begin{array}{l}\text { Weight gain from } \\
\text { birth to } 1 \text { year of } \\
\text { age }(g)\end{array}$ & $\begin{array}{l}\text { Obesity at age } 7 \text { years, } \\
\text { defined as BMI } \geq 95 \text { th } \\
\text { centile relative to UK } \\
1990 \text { reference } \\
\text { population }\end{array}$ & $\begin{array}{l}\text { Logistic regression giving odds } \\
\text { ratio of obesity at } 7 \text { years of } \\
\text { age by rate of weight gain } \\
\text { from birth to } 12 \text { months of } \\
\text { age in units of } 100 \mathrm{~g} \text { per } \\
\text { month }\end{array}$ & $\begin{array}{l}\text { Odds ratio }(95 \% \mathrm{Cl}) 1.07 \text { (1.05 to } 1.10) \text { unadjusted; } \\
1.06(1.02 \text { to } 1.10) \text { adjusted for birth weight, } \\
\text { maternal smoking, parental obesity, hours of sleep } \\
\text { at } 30 \text { months, time spent watching television at } 30 \\
\text { months, diet, maternal education, sex }\end{array}$ & Low \\
\hline $\begin{array}{l}\text { Toschke }(2004)^{32} \\
\text { South Germany }\end{array}$ & $\begin{array}{l}4235(\% \text { male } \\
\text { not stated) } \\
1992-4\end{array}$ & $\begin{array}{l}\text { Weight gain from } \\
\text { birth to } 2 \text { years of } \\
\text { age }(g)\end{array}$ & $\begin{array}{l}\text { Overweight status at } \\
\text { school entry (age } 5 \text { to } \\
6.9 \text { years) according to } \\
\text { IOTF definitions (BMI } \\
\geq 85 \text { th centile for age } \\
\text { and sex) }\end{array}$ & $\begin{array}{l}\text { Odds ratio for overweight at } \\
\text { school entry in children with } \\
\text { weight gain greater }>9764 \mathrm{~g} \text { at } \\
\text { age } 2 \text { years } v \text { those with } \\
\text { weight gain at or below this } \\
\text { level }\end{array}$ & Odds ratio $(95 \% \mathrm{Cl}) 5.7$ (4.5 to 7.1 ) & High \\
\hline
\end{tabular}

life. ${ }^{62} 24$ 28-32 Two studies used increase in weight for age $\mathrm{ar}^{27}$ or weight for height $\mathrm{z}$ scores. ${ }^{19}$

Six studies examined obesity in children, four with body mass index $^{6223032}$ and two with weight. ${ }^{28} 29$ Of two studies of adolescents, one defined obesity according to body mass index and the other used a clinical definition. ${ }^{19}{ }^{24}$ Both the studies of young adults defined obesity by body mass index..$^{27}{ }^{31}$

Seven of the ten studies examining infant growth found that more rapid growth in infancy was associated with greater risk of obesity at ages ranging from 4.5 to 20 years. In four studies of childhood, odds ratios of obesity in children who grew more rapidly in infancy compared with those who grew less rapidly ranged between 1.06 and 5.70..$^{22} 3032$ The studies of adolescents and young adults reported odds ratios of later obesity ranging from 1.41 to $5.22 .^{19} 2731$ The analyses in six of the seven studies were adjusted for important confounding factors, ${ }^{6} 1922273031$ and we considered three studies to have a low risk of bias. ${ }^{19}{ }^{22}{ }^{30}$ Associations between infant growth and later obesity were consistent over time: year of birth ranged from 1945 to 1994. Three studies, two in children and one in adolescents, failed to show an association between infant growth and later obesity. ${ }^{24} 2829$

We could not carry out a meta-analysis of the relation between infant size or growth and later obesity because the definitions of both the exposures (infant size or growth) and outcomes (childhood or adult obesity) varied widely between studies. 


\section{Discussion}

This review suggests that both size and growth during infancy are related to risk of obesity in children and adults. Most studies of infant size found that infants who were defined as "obese" or who were at the highest end of the distribution for weight or body mass index were more likely to develop obesity in childhood, adolescence, or early adulthood than other infants. The evidence relating to infant growth was also consistent across most studies reviewed. Infants who grew more rapidly (usually measured as weight gain) were more likely to be obese in childhood, adolescence, and early adulthood than other infants. There was no evidence to suggest that exposure at a particular time during infancy was critical: larger size or a rapid phase of growth at a range of intervals during the first and second year of life predisposed to later obesity. Associations were also consistent across a range of settings in developed countries; for obesity measured in childhood, adolescence, and early adulthood; and over time for people born from 1927 to 1994.

\section{Strengths and limitations of this review}

Our review used rigorous and standard methods and was supported by an expert advisory group. ${ }^{11}$ There were several challenges in interpreting the evidence. Most studies had at least a medium risk of bias in relation to the review question. Less than half of the studies of infant size took adequate account of confounding factors, though seven of the ten studies of infant growth considered most important confounders. Definitions of both the exposure (infant size or growth) and the outcome (obesity) varied between studies making meta-analysis impossible. This limits our ability to make precise conclusions about the size of the effect, though the consistency of the associations we observed between both infant size and growth and later obesity across a range of settings and time periods suggest that the association is robust

Systematic reviews are subject to publication bias. Although we attempted to limit the impact of this through contact with first authors and experts, we did not identify any unpublished analyses. This review was part of a much larger review and so it was impractical to obtain original data from study authors to carry out secondary analyses. We therefore relied on published data from studies that were of variable quality.

\section{Comparison with other research}

Our findings amplify those of earlier systematic reviews. These found that rapid growth at different ages in childhood was associated with greater risk of later obesity. ${ }^{43}$ One review also found that birth weight was positively associated with adult body mass index. ${ }^{4}$ In our review odds ratios and relative risks of subsequent obesity in infants who had been obese compared with non-obese infants ranged between 1.35 and 9.38. Though not directly comparable, odds ratios tended to be lower in the studies of birth weight. For example, in a study of young Swedish men odds ratio of overweight increased from 1.07 to 1.67 going from the lowest ( $\leq 5$ th centile) to the highest $(>95$ th centile) birthweight group. ${ }^{34}$ In our review both large infant size and rapid infant growth were associated with later obesity. Babies who are small at birth experience rapid growth, at least in early infancy. Taken with other evidence, our review suggests that both prenatal and infant growth trajectories may be important in predicting adult obesity.

\section{Conclusions}

Infants in the highest end of the distribution for weight or body mass index and those who grow rapidly are at increased risk of

\section{What is already known on this topic}

Levels of overweight and obesity are increasing in all age groups

It is not clear how early in life prevention of obesity could begin nor what form it could take

Birth weight and childhood growth are related to risk of adult obesity, but the associations of infant size and growth with obesity have not been systematically assessed

\section{What this study adds}

Infants who are in the highest end of the distribution for weight or body mass index, or who grow rapidly during infancy, are at increased risk of subsequent obesity

Strategies for prevention of childhood and adult obesity may need to address factors during or before infancy that are related to infant growth

obesity in childhood and adulthood. This suggests that factors during infancy or before that are related to infant growth influence the risk of later obesity. To inform public health policy aimed at reducing levels of childhood obesity, future research needs to investigate the determinants of these patterns of growth. The relation of infant growth with other health outcomes should be explored to assess whether interventions to alter infant growth to prevent obesity are likely to be associated with other benefits or harms. It will also be important to assess whether factors influencing infant growth are amenable to change, to establish which strategies might alter infant growth, and to find out whether these are acceptable to parents.

We thank our advisory group for their input to the project, especially Paul Dieppe for chairing it. We also thank Liz Payne for carrying out our searches and colleagues at Medical Research Council Epidemiology Resource Centre, Institute of Child Health, University College London, and the Centre for Reviews and Dissemination, University of York, for their assistance and support. We are grateful to those who have reviewed this project and thank the experts and first authors of papers that we contacted for their assistance.

Contributors: CL, JB, HR, and JK obtained funding. All authors were responsible for the concept and design of the study. JB, DF, and PL carried out the review work with assistance from CL, HR, and JK. All authors were responsible for the interpretation of findings. JB and CL produced the first draft of the paper, and all authors were responsible for critical revision of the manuscript. CL is guarantor.

Funding: Department of Health. JB is an MRC Special training fellow in health services and health of the public research.

Competing interests: None declared.

Ethical approval: Not required.

1 Department of Health. Health survey for England 2003. London: Stationery Office, 2004. Stamatakis E. Anthropometric measurements, overweight, and obesity. In: Sproston K, Primatesta P, eds. Health Survey for England 2002: the health of children and young people, London: Stationery Office, 2002.

3 Summerbell CD, Ashton V, Campbell KJ, Edmunds L, Kelly S, Waters E. Interventions for treating obesity in children. Cochrane Database Syst Rev 2005;2:CD001872.

4 Parsons TJ, Power C, Logan S, Summerbell CD. Childhood predictors of adult obesity: a systematic review. Int J Obes Relat Metab Disord 1999;23:S1-107.

Parsons TJ, Power C, Manor O. Fetal and early life growth and body mass index from birth to early adulthood in 1958 British cohort: longitudinal study. BMJ 2001;323:1331-5.

6 Stettler N, Zemel BS, Kumanyika S, Stallings VA. Infant weight gain and childhood overweight status in a multicenter, cohort study Pediatrics 2002;109:194-9.

Eriksson J, Forsen T, Osmond C, Barker D. Obesity from cradle to grave. Int J Obes Relat Eriksson J, Forsen T, Osmon Metab Disord 2003;27:722-7.

Cole TJ. Secular trends in growth. Proc Nutr Soc 2000;59:317-24

Cole TJ, Belliszi MC, Flegal KM, Dietz WH. Establishing a standard definition for child overweight and obesity worldwide: international survey. BMJ 2000;320:1240-3. 
10 NHS Centre for Reviews and Dissemination. Undertaking systematic reviews of research on effectiveness: CRD's guidance for those carrying out or commissioning reviews. Report No 4. 2nd ed. 2001. York: Centre for Reviews and Dissemination, 2001

11 Whitaker RC, Wright JA, Pepe MS, Seidel KD, Dietz WH. Predicting obesity in young adulthood from childhood and parental obesity. N Engl J Med 1997;337:869-73.

12 Rolland-Cachera MF, Deheeger M, Guilloud-Bataille M, Avons P, Patois E, Sempe M. Tracking the development of adiposity from one month of age to adulthood. Ann Human Biol 1987;14:219-29.

13 Guo SS, Roche AF, Chumlea WC, Gardner JD, Siervogel RM. The predictive value of childhood body mass index values for overweight at age 35 y. Am J Clin Nutr 1994;59:810-9.

14 He Q Karlberg J. Prediction of adult overweight during the pediatric years. Pediatr Res 1999;46:697-703.

15 Tienboon P, Wahlqvist ML. A prospective study of weight and height going from infancy to adolescence. Asia Pac J Clin Nutr 2002;11:42-7.

16 Charney E, Goodman HC, McBride M, Lyon B, Pratt R. Childhood antecedents of adult obesity. Do chubby infants become obese adults? N Engl J Med 1976;295:6-9.

17 Asher P. Fat babies and fat children. The prognosis of obesity in the very young. Arch Dis Child 1966;41:672-3.

18 Poskitt EM, Cole TJ. Do fat babies stay fat? BMJ 1977;i:7-9.

19 Monteiro PO, Victora CG, Barros FC, Monteiro LM. Birth size, early childhood growth, and adolescent obesity in a Brazilian birth cohort. Int J Obes Relat Metab Disord 2003;27:1274-82.

20 Mei Z, Grummer-Strawn LM, Scanlon KS. Does overweight in infancy persist through the preschool years? An analysis of CDC pediatric nutrition surveillance system data. Soz Praventivmed 2003;48:161-7.

21 Garn SM, LaVelle M. Two-decade follow-up of fatness in early childhood. Am J Dis Child 1985;139:181-5.

22 Reilly J, Armstrong J, Dorosty AR, Emmett PM, Ness A, Rogers I, et al. Early life risk factors for obesity in childhood: cohort study. BMJ 2005;330:1357.

23 Wilkinson PW, Parkin JM, Pearlson J, Philips PR, Sykes P. Obesity in childhood: a community study in Newcastle upon Tyne. Lancet 1977;i:350-2.

24 Heald FP, Hollander RJ. The relationship between obesity in adolescence and early growth. J Pediatr 1965;67:35-8.

25 Johnston FE, Mack RW. Obesity in urban black adolescents of high and low relative weight at 1 year of age. Am J Dis Child 1978;132:862-4.

26 Mossberg HO. 40-year follow-up of overweight children Lancet 1989;ii:491-3.

27 Stettler N, Kumanyika SK, Katz SH, Zemel BS, Stallings VA. Rapid weight gain during infancy and obesity in young adulthood in a cohort of African Americans. Am J Clin Nutr 2003;77:1374-8.
28 Eid EE. Follow-up study of physical growth of children who had excessive weight gain in first six months of life. BMJ 1970;ii:74-6.

29 Mellbin T, Vuille JC. Physical development at 7 years of age in relation to velocity of weight gain in infancy with special reference to incidence of overweight. BrJ Prev Soc Med 1973;27:225-35.

30 Stettler N, Bovet P, Shamlaye H, Zemel BS, Stallings VA, Paccaud F. Prevalence and risk factors for overweight and obesity in children from Seychelles, a country in rapid transition: the importance of early growth. Int J Obes Relat Metab Disord 2002;26:214-9.

31 Stettler N, Stallings VA, Troxel AB, Zhao J, Schinnar R, Nelson BA, et al. Weight gain in the first week of life and overweight in adulthood: a cohort study of European American subjects fed formula milk. Circulation 2005;111:1897-903.

32 Toschke AM, Grote V, Koletzko B, von Kries R. Identifying children at high risk for overweight at school entry by weight gain during the first 2 years. Arch Pediatr Adolesc Med 2004:158:449-52.

33 Monteiro POA, Victora CG. Rapid growth in infancy and childhood and obesity in later life-a systematic review. Obes Rev 2005;6:143-54

34 Rasmussen F, Johansson M. The relation of weight, length and ponderal index at birth to body mass index and overweight among 18-year old males in Sweden. Eur J Epidemiol 1998;14:373-80.

(Accepted 16 August 2005)

doi 10.1136/bmj.38586.411273.E0

MRC Epidemiology Resource Centre, University of Southampton, Southampton General Hospital, Southampton SO16 6YD

Janis Baird research fellow

David Fisher research assistant

School for Policy Studies, University of Bristol, Bristol BS8 1TZ

Patricia Lucas lecturer

Centre for Reviews and Dissemination, University of York, York YO10 5DD

Jos Kleijnen director

Child Health Research and Policy Unit, City University, London EC1Y 4TY

Helen Roberts professor of child health

Centre for Paediatric Epidemiology and Biostatistics, Institute of Child Health,

University College London, London WC1N 1EH

Catherine Law reader in children's health

Correspondence to:J Baird jb@mrc.soton.ac.uk 